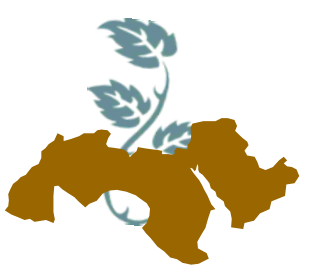

Arab Univ.

J. Agric. Sci., Ain Shams Univ., Cairo, 26(1), 359-372, 2018

\title{
POTENTIALITY OF USING A. PINNATA TO BIOREMEDIATE DIFFERENT HEAVY METALS FROM POLLUTED DRAINING WATER
}

Rabab, R. Hanafy ${ }^{1}$; Wedad, E. Eweda ${ }^{1}$; Mona, S. Zayed ${ }^{1}$ and Heba, M.A. KhaliI ${ }^{2}$

1- Microbial Inoculants Unit., Agric. Microbiology Dept.,, Fac. of Agric. Ani Shams Univ., Cairo, Egypt

2- Soils Water and Environment. Institute. (SWEI), Agric. Res. Center (ARS), Giza, Egypt

Keywords: Azolla pinnata, phytoremediation, heavy metals, polluted draining water, $\mathrm{Pb}^{+2} \mathrm{Co}^{+2}$ and $\mathrm{Cu}^{+2}$.

\section{ABSTRACT}

Azolla pinnata is a small aquatic fern which considered as a multipurpose organism. It is used in bioremediation to remove heavy metals from polluted draining waters. In view of its potentiality, Azolla pinnata were tested for their growth on different media (Yoshida, peat moss, and Soil media) to select the best medium for the growth of Azolla. Then the best medium was examined for the potentiality of Azolla to withstand a different concentration of different heavy metals. Yoshida medium was the most suitable medium, as it recorded the highest significant records in fresh and dry weight, being 25.38 and $1.69 \mathrm{~g} /$ pot respectively, the doubling time was 5.43 days, NPK\% being $3.87,0.85$ and $1.95 \%$ respectively and nitrogenase activity being $14.32 \mu \mathrm{mol} \mathrm{C}_{2} \mathrm{H}_{4} / \mathrm{g}$ dry weight. / hr). The fresh and dry weight of Azolla exposed to $\mathrm{Pb}^{+2}, \mathrm{Co}^{+2}$ or $\mathrm{Cu}^{+2}$, was found to be increased by increasing the concentration of the metals from 5 to $35 \mathrm{ppm} / \mathrm{liter}$, then they decreased when the fern exposed to $45 \mathrm{ppm} / \mathrm{liter}$ for all of them. While, doubling time decreased gradually by increasing the concentration of $\mathrm{Pb}^{+2}, \mathrm{Co}^{+2}$ or $\mathrm{Cu}^{+2}$ from 5 to 35 $\mathrm{ppm} /$ liter and started to increase by increasing the concentration of $\mathrm{Pb}^{+2}$ to $45 \mathrm{ppm} / \mathrm{liter}$ in the medium.

\section{INTRODUCTION}

Azolla sp. is a small, free-floating fern, less than $1 / 2$ inches diameter (Ferentinos et al 2002). It is a fern frond consisting of the main stem growing on the surface of the water, with alternate leaves and adventitious roots at regular intervals along the stem (IFAS, 2001). It has a symbiotic relationship with the blue-green algae Anabaena (Peters and Mayne, 1974 \& Wagner, 1997). The word Azolla has a Greek origin. It consists of two words, azo and olly, which means killed by drought (Moore, 1969 \& Ashton and Walmsley, 1976). It has common names of Mosquito Fern, Water velvet, Water fern or simply Azolla is a water fern commonly found in tropical and temperate freshwater ecosystem.

Water contaminated by heavy metals is considered one of the most important environmental problems throughout the world because of their toxic effect on the environment and human health (Akpor and Muchie, 2010). A high concentration of lead can be found in industrial wastewater, in domestic detergents and other laundry products and in cigarettes (Celebi and Kendir, 2002). While contamination of aquatic ecosystems with copper is normally due to various anthropogenic sources including copper mine drainage, copper-based pesticides, industrial, domestic wastes and antifouling paints (Andrade et al 2004; Ma et al 2003 \& Rai, 2009). Cobalt can enter the aquatic environment from a number of sources, both natural and anthropogenic. The natural sources include volcanic emissions, the weathering of rocks by the action of water and decomposition of plant wastes.

The presence of heavy metals pollutants in water bodies possess several risks to the health of humans and ecosystems (Ho et al 2003; Alam et al 2003; Miller et al 2004 \& Rai 2008a, 2009). 
The term "phytoremediation" is a combination of two words: Greek "phyto" meaning plant and Latin "remediation" meaning to correct or remove an evil (Hazrat et al 2013). While the clear descriptions of the term, phytoremediation is "the use of plants for removal of pollutants from the environment "as it promotes the use of plants for environmental cleanup (Gardea, 2003). Phytoremediation also called green remediation, botano-remediation, agro-remediation and vegetative remediation (Erakhrumen, 2007).

The ability of different plants to remove the toxicity of heavy metals in the environment have been extensively and excellently reviewed by several authors (Orcutt and Nilsen, 2000; Cseh, 2002; Fodor, 2002; Zimmels et al 2004; Pilon, 2005 \& Migocka and Klobus, 2007).

The use of aquatic macrophytes, such as $A z-$ olla that has hyperaccumulating ability is known to be an environmentally friendly option to restore polluted aquatic resources because of it has short doubling time (3-5 days), easy harvest, nitrogen fixation ability and tolerance to and accumulation of a wide range of heavy metals (Sood et al 2012; Rai, 2007; Bennicelli et al 2004; Upadhyay et al 2007; Rai, 2008b \& Mashkani and Ghazvini, 2009). Remediation of heavy metals using plants is better in terms of ecology and economy than chemical treatment (Rai, 2011).

The present research highlights the phytoaccumulation potential of Azolla as a promising candidate for phytoremediation. The impact of uptake of heavy metals on the growth of Azolla has also been discussed for a better understanding and utilization of this symbiotic association for application as a phytoremediation agent in the field.

\section{MATERIALS AND METHODS}

\section{Azolla Pinnata Strain}

Azolla Pinnata was kindly provided by Agric. Microbial Dept. Soils, Water and Environment Research Institute (S.W.E.R.I), Agric.Res. Center (A.R.C), Giza, Egypt.

\section{Azolla growth media}

Modified Yoshida medium (Yoshida et al 1976), peat moss medium, and soil were used. The peat moss medium was prepared by adding $(20 \mathrm{~g})$ peat moss to $(600 \mathrm{ml})$ tap water to each used plastic pot. The composition of peat moss was estimated by El-Shahat (1988).

\section{Soil medium}

The soil was collected from Kaliobia Governorate to study the ability of Azolla to grow on it. Soil analyses were estimated according to El-Shahat (1988).

\section{Propagation of Azolla Pinnata}

The experiment was carried out in the greenhouse of Soils, Water, and Environmental Res. Ins. (SWERI), Agric. Res. Center (ARC), Giza, Egypt.

One gram of Azolla Pinnata was transferred into plastic pots $20 \mathrm{~cm}$ diameter and $25 \mathrm{~cm}$ in depth in 5 replicates to estimate the growth of Azolla Pinnata during 25 days samples were taken every 5 days. The inoculated pots were incubated at 35 ${ }^{\circ} \mathrm{C} \pm 2$, with $14 \mathrm{~h}$. light and $10 \mathrm{~h}$. dark for 25 days under greenhouse conditions (EL-Berashi, 2008).

\section{Parameters measured}

Fresh weight and dry weight were determined according to El-Shahat, (1997), and they expressed as $\mathrm{g} /$ pot.

Doubling time: was calculated according to Aziz and Watanabe, (1983), by using the following equation:

\section{D. $\mathrm{T}=\mathrm{t} / \mathrm{r}$ whereas:}

$\mathrm{t}=$ the duration of Azolla growth

$r=\{\log (w t / w 0) / 0.301\}$

wt $=$ weight of Azolla at time $t$

w0 = weight of Azolla at zero time, (weight of inoculum).

\section{Total nitrogen:}

Total nitrogen (\%) of Azolla fronds was determined in the dried plant materials by the micro kjedahl method according to Black et al (1965).

\section{Phosphorus percentage:}

Phosphorus percentage in Azolla fronds was determined in dried samples by Spectrophotometer according to Olsen and Sommers (1982).

\section{Potassium content}

It was determined in plant samples by Flame photometer according to Brown and Lilliland (1946) data exposed as K \% of Dry weight. 

Heavy metals

\section{Nitrogenase activity}

Nitrogenase activity in Azolla was assayed by using the acetylene reduction technique as recommended by Hardy et al (1973).

Cultivation of $\boldsymbol{A}$. Pinnata in Yoshida medium supplemented with different heavy metals

A. Pinnata was inoculated by $(1 \mathrm{~g})$ fresh weight per pot, as standard inoculums in all experiments (El-Berashi, 2008 \& Punita and Soma, 2015). The pots were filled with $1000 \mathrm{ml}$ of Yoshida medium and supplemented with different concentrations of $\mathrm{Pb}^{+2} \mathrm{Co}^{+2}$ or $\mathrm{Cu}^{+2}$. Three replicates were prepared for each treatment.

Synthetic wastewater samples were prepared by dissolving their corresponding analytical grade salts of $\mathrm{Pb}\left(\mathrm{NO}_{3}\right)_{2}, \mathrm{Co}\left(\mathrm{NO}_{3}\right)_{2} \cdot 6 \mathrm{H}_{2} \mathrm{O}$ or $\mathrm{CuSO}_{4} \cdot 5 \mathrm{H}_{2} \mathrm{O}$ in deionized water at different concentrations 0,5 , 15, 25, 35 and 45 ppm.

The inoculated pots were incubated at $35^{\circ} \mathrm{C} \pm 2$, under $14 \mathrm{~h}$. light (14-17.5 K lux light intensity) and 10 h. dark for 25 days in greenhouse conditions. Samples were taken each five days, using the method adapted by EL-Berashi, (2008).

\section{Parameters recorded}

Fresh weight, dry weight ( $\mathrm{g} / \mathrm{pot}$ ) and doubling time (day) of Azolla Pinnata. Azolla cultures were estimated every 5 days.

\section{Statistical analysis}

The experiments were carried out as a complete randomized design with three replicates. The statistical analysis was carried out using LSD test to compare means of treatments in experiment (SAS. 2006. Statistical Analysis System, SAS User's Guide: Statistics. SAS Institute Inc. Editors, Cary, NC). Statistical significance was defined as $p$ $<0.05$.

\section{RESULTS AND DISCUSSION}

\section{Growth performance of Azolla pinnata in differ- ent media}

This experiment was conducted to determine the ability of $A$. pinnata to grow on different media. It was inoculated in three different media namely Yoshida, peat moss and Soil media to select the best growth medium by measuring the growth parameters as fresh and dry weight, doubling time, NPK content and Nitrogenase activity.
The data depicted in (Figs. 1 and 2) show good growth performance of $A$. pinnata in all the tested media. The fresh and dry weight of $A$. pinnata was gradually increased by increasing the incubation periods. The highest fresh and dry weight was recorded within Yoshida medium being 25.38 and $1.69 \mathrm{~g} /$ pot fresh and dry weight, respectively after 25 days from inoculation compared to Peat moss and Soil media, these results are in similar to those obtained by El-Araby et al (1999), who found that $A$. pinnata recorded its maximum growth with increasing the incubation period up to 25 days of growth on the same medium.

Data recorded in (Fig. 3) show that, doubling time of $A$. pinnata increased during incubation period in the first ten days (from 0 to 10 days) in the three tested media then started to decrease during the second 10 days (from 10 to 20 days), then started to increase again after the second 10 days. In accordance with the highest fresh and dry weight of $A$. pinnata at which it was recorded after 25 days in all the tested media, the lowest doubling time was recorded with Soil medium and Peat moss medium, being (5.43 days) for both media.

It should be mentioned the obtained results by Nuzhat et al (2015), stated that $A$. pinnata doubles its biomass in less than two days under laboratory conditions and 5-10 days in normal field conditions.

Nitrogenase activity profile during incubation period (Fig. 4) showed gradual increase during the incubation period. The maximum nitrogenase activity was recorded in Yoshida medium after 25 days, being $14.32 \mu \mathrm{mol} \mathrm{C}_{2} \mathrm{H}_{4} / \mathrm{g}$ dry weight $/ \mathrm{h}$. while both of Soil and Peat moss media recorded their highest Nitrogenase activity after 20 days from inoculation being (13.29 and $7.63 \mu \mathrm{mol} \mathrm{C}_{2} \mathrm{H}_{4} / \mathrm{g}$ dry weight $/ h$.) respectively.

These results are in agreement with those of (Abd El-AAl et al 2013), who stated that nitrogenase activity of Anabaena Azolla increased gradually by increasing the incubation period. While Pabby et al (2004) reported that prolonged incubation for more than 14 days, in a medium led to the suppression of nitrogenase activity in Anabaena microphylla.

The total NPK in $A$. pinnata recorded in (Figs. 5, 6 and 7) show that total NPK\% increased gradually during the incubation period in all the three tested media and they reached their maximum record after 25 days in Yoshida medium compared to the other tested media. The highest significant NPK\% was recorded within Yoshida medium after 25 days from inoculation being $3.87,0.85$ and $1.95 \%$ respectively. 


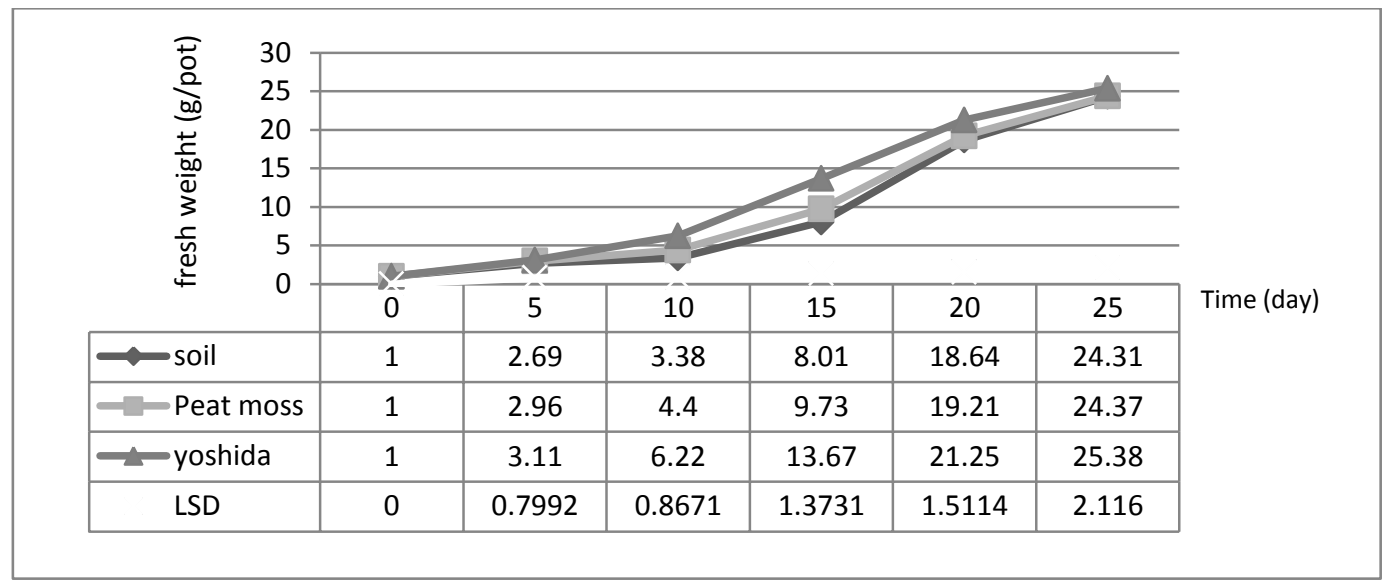

Fig. 1. Fresh weight (g/pot) of Azolla pinnata during 25 days of growth on the media used.

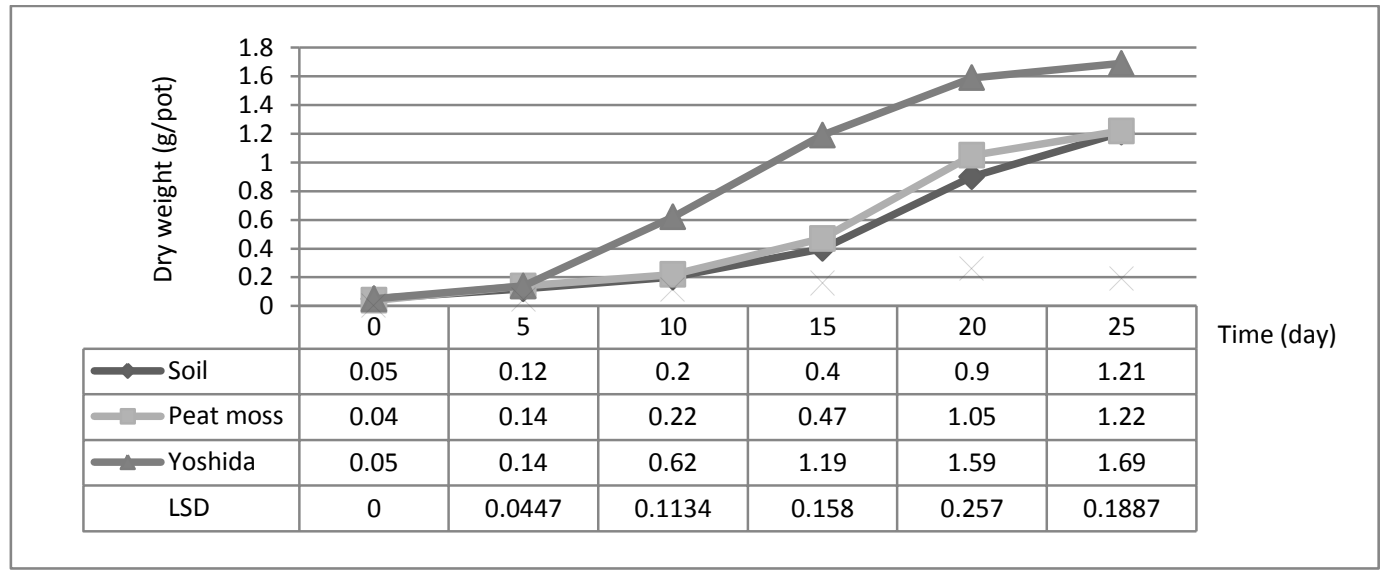

Fig. 2. Dry weight (g/pot) of Azolla pinnata during 25 days of growth on the media used.

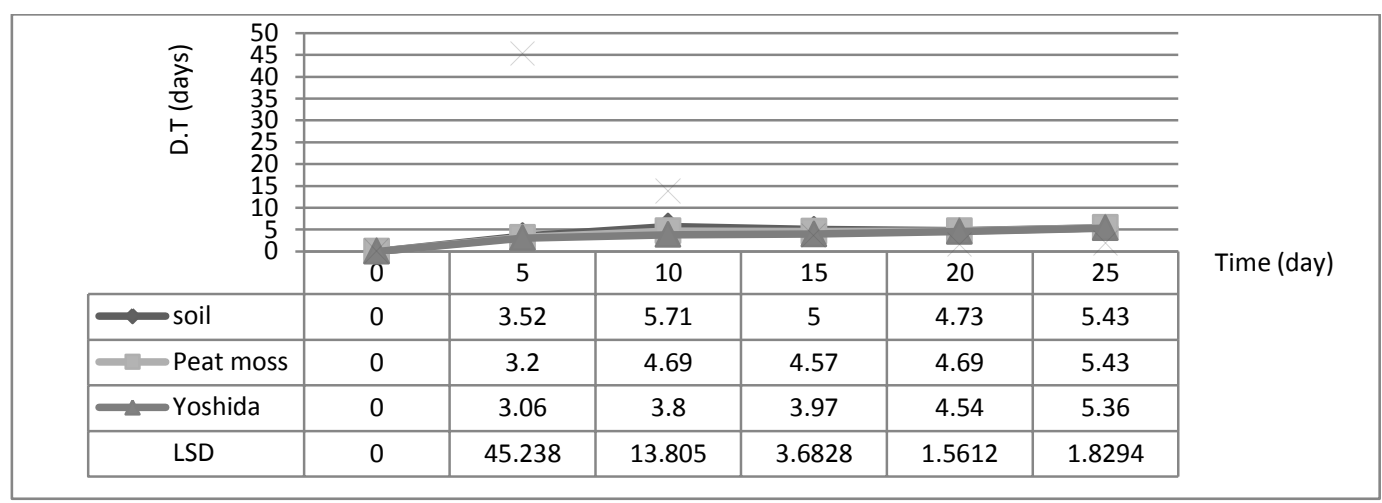

Fig. 3. Doubling time (days) of Azolla pinnata during 25 days of growth on the media used. 


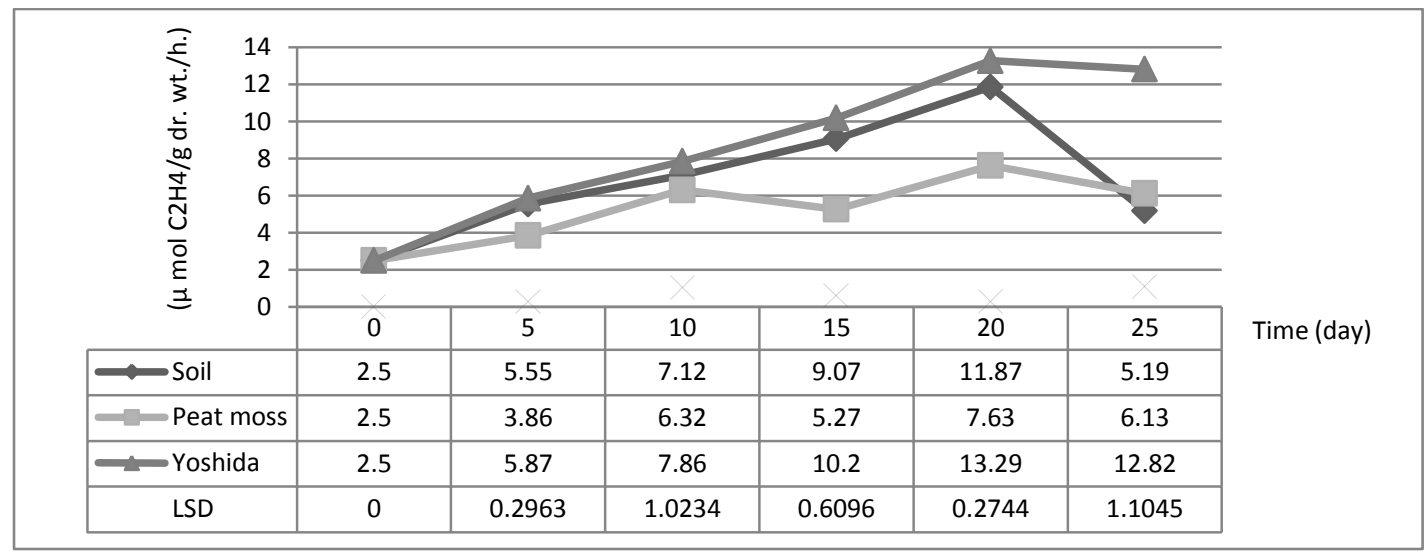

Fig. 4. Nitrogenase activity ( $\mu \mathrm{mol} \mathrm{C2H4/g} \mathrm{dr.} \mathrm{wt./hr.)} \mathrm{of} \mathrm{Azolla} \mathrm{pinnata} \mathrm{during} 25$ days of growth on the media used

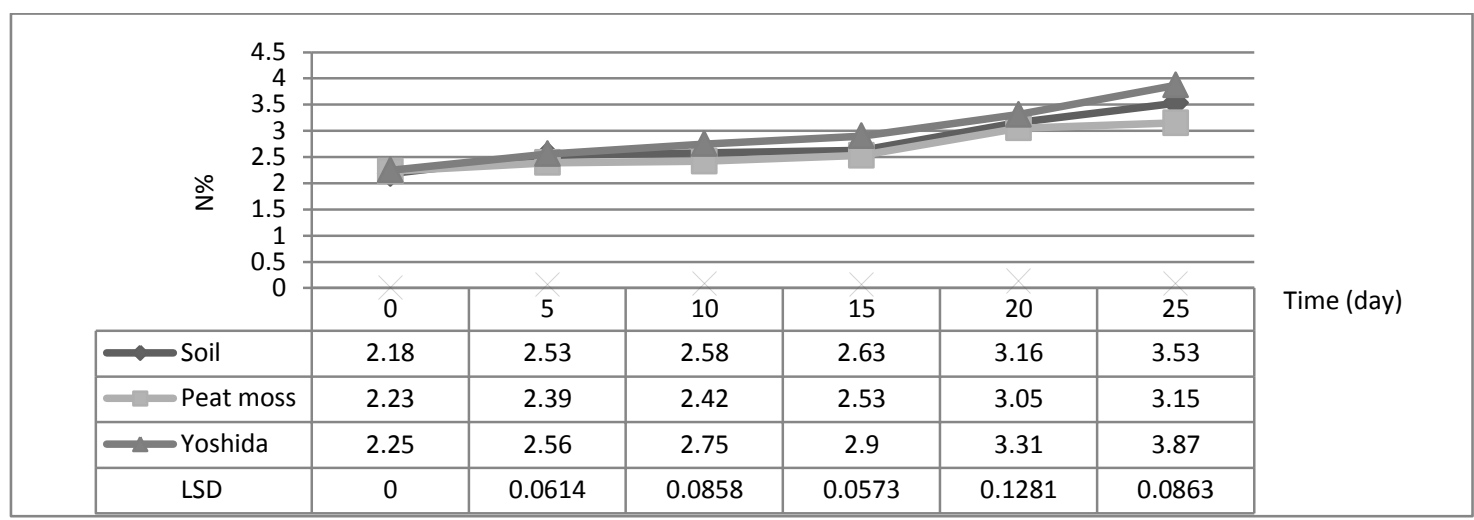

Fig. 5. Nitrogen content (\%) of Azolla pinnata during 25 days of growth on the media used.

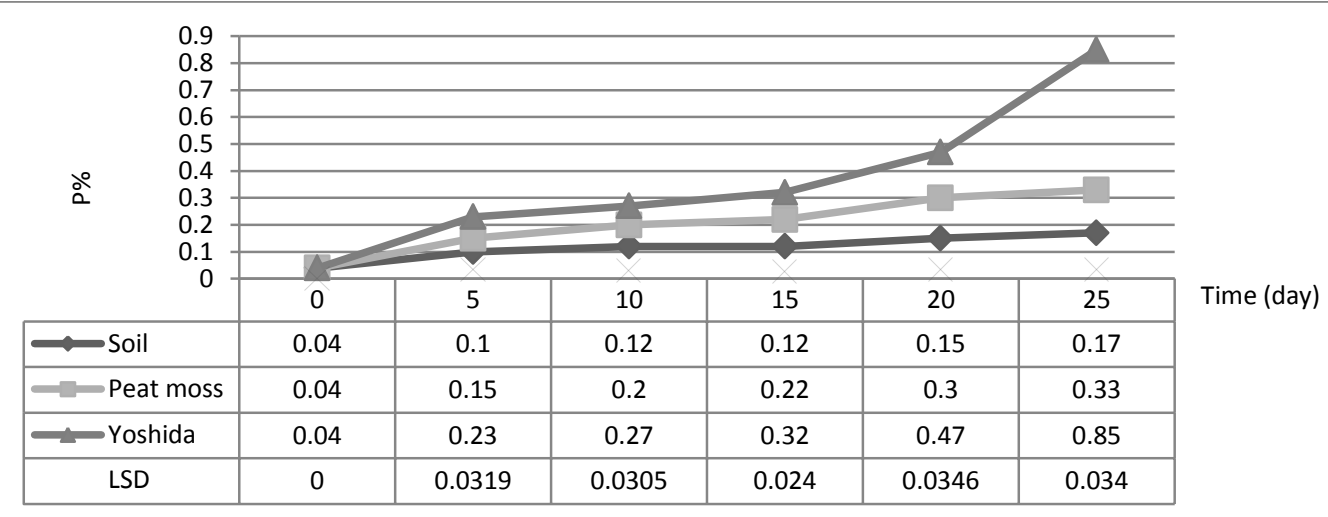

Fig. 6. Phosphors content (\%)of Azolla pinnata during 25 days of growth on the media used. 


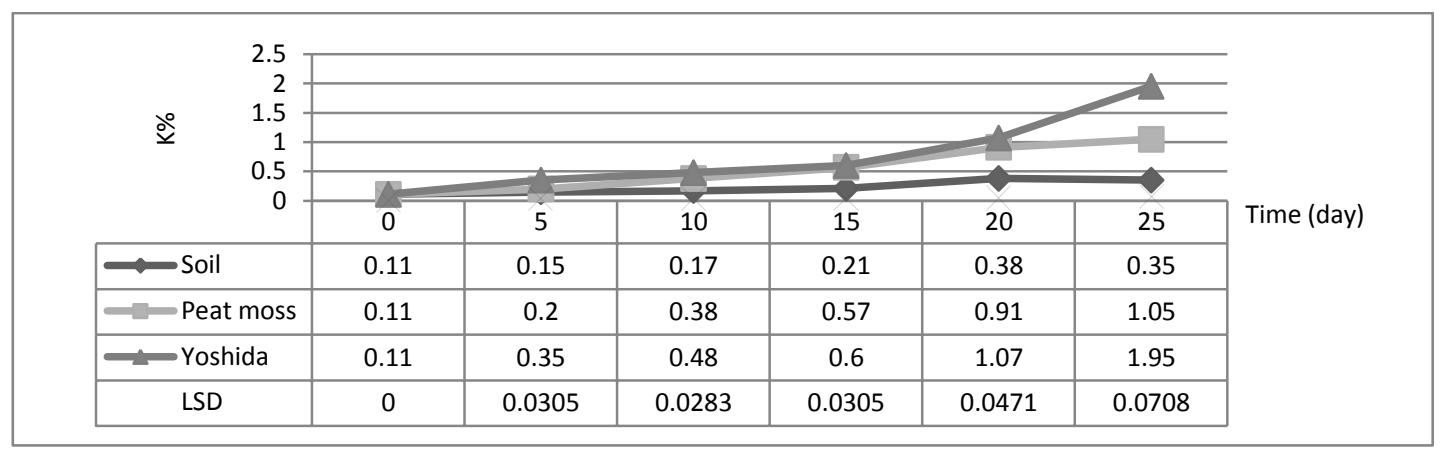

Fig. 7. Potassium content (\%) of Azolla pinnata during 25 days of growth on the media used

Similar results are in agreement with those recorded by El-Shaymaa, (2005), who showed that in Yoshida medium, $A$. pinnata gave its highest value of total nitrogen content compared to soil and Van Hove media after $30^{\text {th }}$ days of incubation. Also, Nour El-Din, (1997) found that total nitrogen percentage of $A$. pinnata reached to $5.10 \%$ after 25 days of incubation.

The results of this experiment validate that Yoshida medium is considered the best medium for the best performance of Azolla this statement was similar with those reported by El-Shaymaa, (2005) \& Shoe and Anita, (2011), who reported that Yoshida medium is considered the most suitable medium as it had the essential nutrients needed for Azolla growth.

Growth performance of Azolla pinnata during incubation period as affected by the addition of $\mathrm{Pb}^{+2}$ on Yoshida medium.

Data recorded in (Figs 8 and 9) revealed that fresh and dry weight of Azolla increased in all treatments by increasing incubation periods until the $20^{\text {th }}$ day, then started to decrease. Also, the fresh and dry weight of Azolla exposed to $\mathrm{Pb}^{+2}$ in the form of $\mathrm{Pb}\left(\mathrm{NO}_{3}\right)_{2}$ recorded an increase by increasing the concentration of $\mathrm{Pb}^{+2}$ from 5 to 35 $\mathrm{ppm} /$ liter then they decrease values when it exposed to $45 \mathrm{ppm} /$ liter of $\mathrm{Pb}^{+2}$. The highest significant fresh and dry weight were recorded within Azolla inoculated in Yoshida medium treated with $\mathrm{Pb}^{+2} 35 \mathrm{ppm} /$ liter after 20 days from inoculation, being 9.5 and $0.57 \mathrm{~g} /$ pot respectively.

Data recorded in (Fig. 10) show that inoculation of Azolla in Yoshida medium contain $\mathrm{Pb}^{+2}$ in the form of $\mathrm{Pb}\left(\mathrm{NO}_{3}\right)_{2}$ recorded decrease gradually in the doubling time by increasing the concentration of $\mathrm{Pb}^{+2}$ from 5 up to $35 \mathrm{ppm} /$ liter then doubling time started to increase by increasing the concentration of $\mathrm{Pb}^{+2}$ to $45 \mathrm{ppm} /$ liter in the medium, as well, the doubling time of Azolla increased by increasing incubation period. The lowest doubling time was recorded within Azolla inoculated in Yoshida medium that contains $35 \mathrm{ppm} / \mathrm{liter}$, being 6.17days.

These results are in agreement with those reported by Monica et al (2014), who stated that Azolla pinnata doesn't express any noticeable toxicity symptoms in low concentrations from $\mathrm{Pb}$ $\left(\mathrm{NO}_{3}\right)_{2 .}$. Also, Thayaparan et al (2013), reported that the relative growth of $A$. pinnata exposed to lead was significantly reduced when metal concentration was increased.

In this respect, Arora et al (2006), reported that $A$. pinnata have the ability to absorb $\mathrm{Pb}$, and other heavy metals and showed tolerance when present in low concentrations.

Growth performance of Azolla pinnata during incubation period as affected by the addition of $\mathrm{Co}^{+2}$ on Yoshida medium.

Data recorded in (Fig 11 and 12) show an increase in the fresh and dry weight of Azolla by increasing the incubation period until the $20^{\text {th }}$ day then started to decrease. The fresh and dry weight of Azolla exposed to $\mathrm{Co}^{+2}$ in the form of $\mathrm{CO}\left(\mathrm{NO}_{3}\right)_{2} \cdot 6 \mathrm{H}_{2} \mathrm{O}$ increased gradually by increasing the concentration of $\mathrm{Co}^{+2}$ from 5 to $35 \mathrm{ppm}$, then it recorded lower value when it exposed to $45 \mathrm{ppm}$. The highest significant dry weight was recorded with Azolla growth on Yoshida medium treated with $45 \mathrm{ppm}$, being (0.72 g/pot). While the highest significant fresh weight was recorded within Azolla pinnata inoculated in Yoshida treated with $15 \mathrm{ppm}$ $\mathrm{Co}^{+2}$ after 20 days from inoculation, being (9.8 g/pot). 

Heavy metals

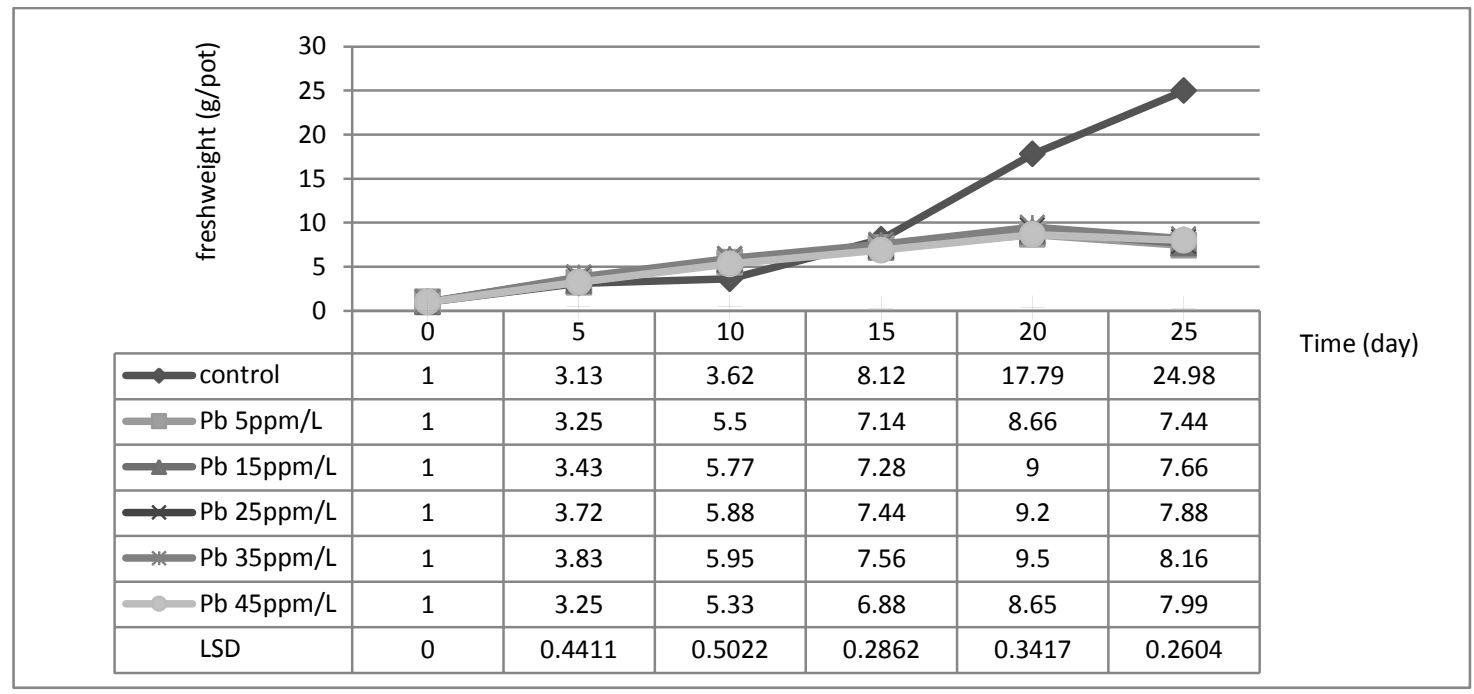

Fig. 8. Effect of different concentrations of $\mathrm{Pb}^{+2}$ on fresh weight (g/pot) of Azolla pinnata grown on Yoshida medium

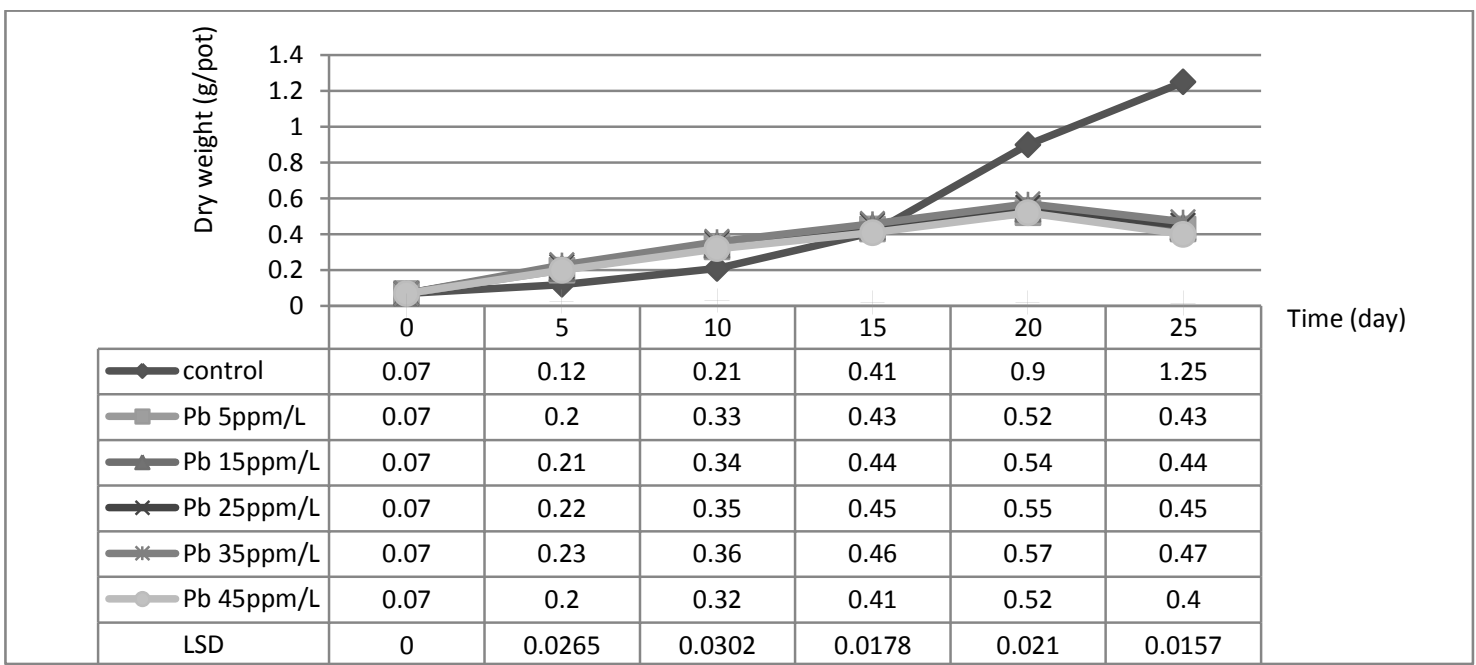

Fig. 9. Effect of different concentrations of $\mathrm{Pb}^{+2}$ on dry weight(g/pot) of Azolla pinnata grown on Yoshida medium 


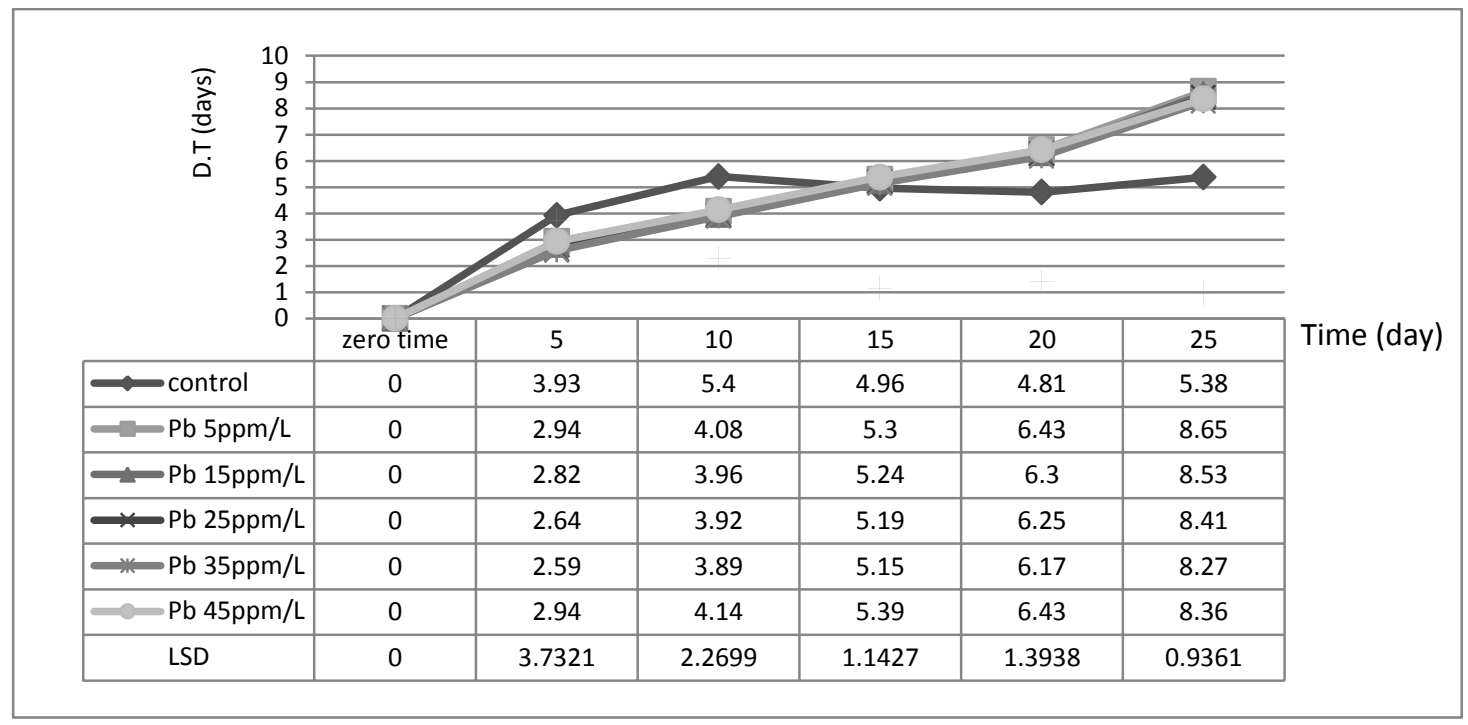

Fig. 10. Effect of different concentrations of $\mathrm{Pb}^{+2}$ on doubling time(days)of Azolla pinnata grown on Yoshida medium

\begin{tabular}{|c|c|c|c|c|c|c|c|c|}
\hline \multirow{6}{*}{ 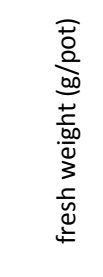 } & 30 & & & & & & & \multirow{13}{*}{ Time (day) } \\
\hline & 25 & & & & & & & \\
\hline & 15 & & & & & & & \\
\hline & 5 & \multirow{2}{*}{\multicolumn{6}{|c|}{$B=$}} & \\
\hline & 0 & & & & & & & \\
\hline & & 0 & 5 & 10 & 15 & 20 & 25 & \\
\hline \multicolumn{2}{|c|}{$\longrightarrow$ control } & 1 & 3.11 & 3.22 & 8.13 & 18.81 & 24.77 & \\
\hline \multicolumn{2}{|c|}{- Co $5 p p m / L$} & 1 & 3 & 4.85 & 7.5 & 9.15 & 7.1 & \\
\hline \multicolumn{2}{|c|}{$\longrightarrow$ Co $15 p p m / L$} & 1 & 3 & 5 & 7.77 & 9.8 & 6.7 & \\
\hline \multicolumn{2}{|c|}{$\nVdash$ Co $25 \mathrm{ppm} / \mathrm{L}$} & 1 & 3.5 & 5.45 & 7.9 & 9.5 & 5.8 & \\
\hline \multicolumn{2}{|c|}{$\because C o 35 p p m / L$} & 1 & 3.75 & 6 & 7.8 & 9.33 & 5 & \\
\hline \multicolumn{2}{|c|}{- Co 45ppm/L } & 1 & 3.36 & 5.12 & 7.55 & 9.2 & 4.47 & \\
\hline \multicolumn{2}{|c|}{ LSD } & 0 & 0.3694 & 0.2474 & 0.4856 & 0.4297 & 0.6365 & \\
\hline
\end{tabular}

Fig. 11. Effect of different concentrations of $\mathrm{Co}^{+2}$ on fresh weight(g/pot) of Azolla pinnata grown on Yoshida medium 

Heavy metals

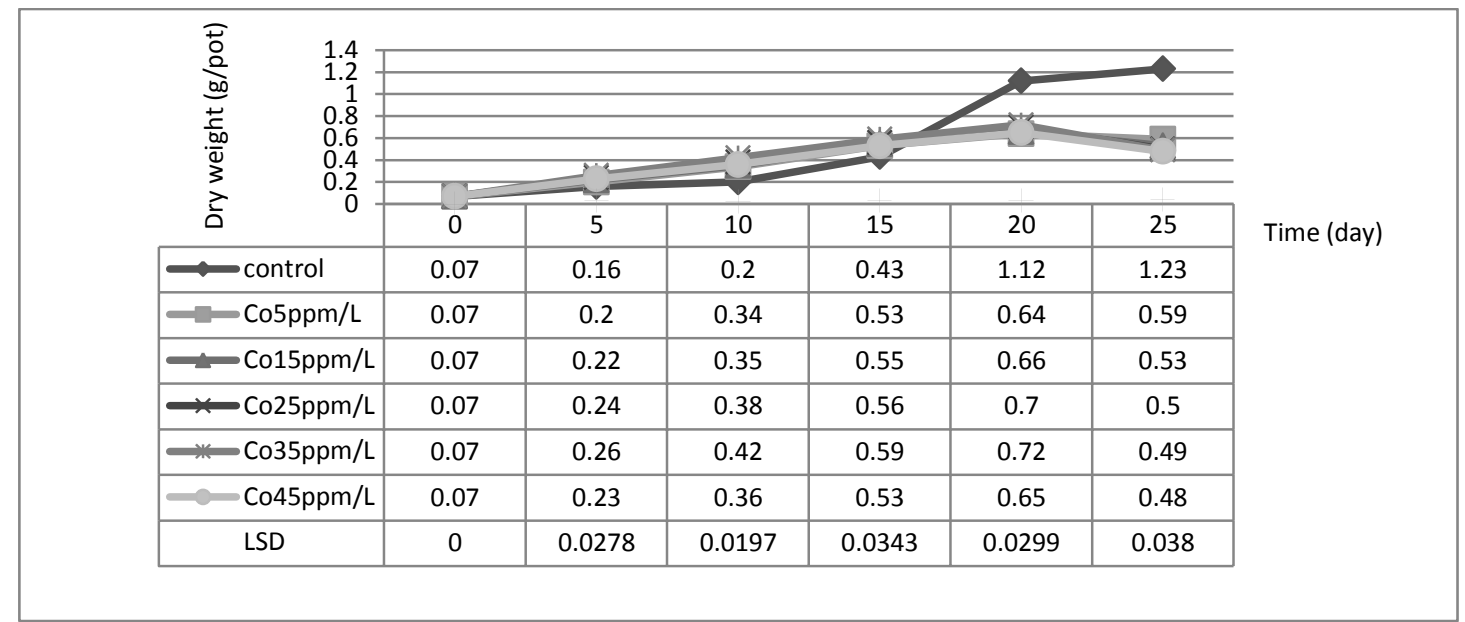

Fig. 12. Effect of different concentrations of $\mathrm{Co}^{+2}$ on dry weight (g/pot) of Azolla pinnata grown on Yoshida medium

Data recorded in (Fig. 13) show that inoculation of Azolla in Yoshida medium containing $\mathrm{Co}^{+2}$ in the form of $\mathrm{CO}\left(\mathrm{NO}_{3}\right)_{2} \cdot 6 \mathrm{H}_{2} \mathrm{O}$ gradually decreased doubling time such decrease was conceded with increasing the concentration of $\mathrm{Co}^{+2}$ in the medium from 5 to $35 \mathrm{ppm}$ and starting to increase by increasing the concentration of $\mathrm{Co}^{+2}$ to $45 \mathrm{ppm}$ in the medium. Also, the doubling time of Azolla increased by increasing the incubation period. After 20 days from inoculation, Azolla exerted the high est significant fresh and dry weight, the lowest doubling time was observed within Azolla inoculated in Yoshida medium that contains $25 \mathrm{ppm}$ from $\mathrm{Co}^{+2}$, being (6.07 days).

El- Berashi (2008), indicated that by increasing the concentration of the heavy metals in the growth medium and incubation period, the doubling time would increase which is an indicator for decreasing the growth rate of $A$. pinnata.

\begin{tabular}{|c|c|c|c|c|c|c|c|}
\hline \multirow[t]{2}{*}{ 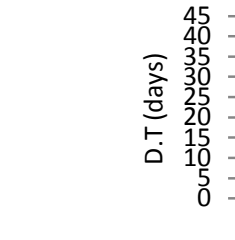 } & \multicolumn{6}{|c|}{ (n) } & \multirow{9}{*}{ Time (day) } \\
\hline & zeró time & 5 & 10 & 15 & 20 & 25 & \\
\hline$\sim$ control & 0 & 3.06 & 5.95 & 4.96 & 4.72 & 5.39 & \\
\hline$=$ Co $5 \mathrm{ppm} / \mathrm{L}$ & 0 & 3.37 & 4.4 & 5.17 & 6.26 & 8.86 & \\
\hline$\simeq$ Co $15 \mathrm{ppm} / \mathrm{L}$ & 0 & 3.16 & 4.31 & 5.08 & 6.17 & 9.12 & \\
\hline$\because$ Co $25 \mathrm{ppm} / \mathrm{L}$ & 0 & 2.77 & 4.09 & 5.03 & 6.07 & 9.88 & \\
\hline$\approx$ Co $35 \mathrm{ppm} / \mathrm{L}$ & 0 & 2.63 & 3.87 & 4.88 & 6.21 & 10.77 & \\
\hline$-\mathrm{Co} 45 \mathrm{ppm} / \mathrm{L}$ & 0 & 2.87 & 4.25 & 5.15 & 6.25 & 11.57 & \\
\hline LSD & 0 & 35.532 & 1.4894 & 2.1213 & 1.2455 & 39.658 & \\
\hline
\end{tabular}

Fig. 13. Effect of different concentrations of $\mathrm{Co}^{+2}$ on doubling time(days)of Azolla pinnata grown on Yoshida medium 
Growth performance of Azolla pinnata during incubation period as affected by the addition of $\mathrm{Cu}^{+2}$ on Yoshida medium

Data recorded in (Figs. 14 and 15) show that inoculation of Azolla in Yoshida medium contain $\mathrm{Cu}^{+2}$ in form of $\mathrm{CuSO}_{4} .5 \mathrm{H}_{2} \mathrm{O}$ exerted slight increase in the fresh and dry weight of Azolla in the first 20 days from incubation period. Increasing the concentration from 5 to $45 \mathrm{ppm}$ the both parameters started to decrease. While from the $20^{\text {th }}$ to the $25^{\text {th }}$ day, the fresh and dry weight of Azolla decreased by increasing the concentration of the $\mathrm{Cu}^{+2}$. The highest significant increase in fresh weight was recorded within Azolla in Yoshida contain $15 \mathrm{ppm} \mathrm{Cu}^{+2}$ after 20 days, being 5.36 and dry weight in $5 \mathrm{ppm} \mathrm{Cu}^{+2}$ after 20 , being $0.43 \mathrm{~g} /$ pot.

Data presented in (Fig 16) revealed that inoculation of Azolla in Yoshida medium contain $\mathrm{Cu}^{+2}$ in the form of $\mathrm{CuSO}_{4} .5 \mathrm{H}_{2} \mathrm{O}$ recorded lower values of doubling time by increasing the concentration of $\mathrm{Cu}^{+2}$ in the medium from 5 to $35 \mathrm{ppm}$ and starting to increase by increasing the concentration of $\mathrm{Cu}^{+2}$ to $45 \mathrm{ppm}$ in the medium. Likewise, the doubling time of Azolla increased by increasing the incubation period in all $\mathrm{Cu}^{+2}$ concentrations. After 20 days from the inoculation at which Azolla revealed the highest significant fresh and dry weight, the lowest doubling time was recorded within Azolla inoculated in Yoshida medium that contains $5 \mathrm{ppm}$ from $\mathrm{Cu}^{+2}$, being (8.26 days).

Arora et al (2006), reported that exposing $A z-$ olla to heavy metals suppressed the vegetative growth and sporulation in different species and the suppression percentage depends on the species and the concentration of heavy metals.

Rai (2008a), reported that copper solution at low concentration is essential to develop the growth of $A$. pinnata while in higher concentration the color of Azolla changed into yellow which cause suppression in $A$. pinnata's growth when it exposed to copper. While Wagner, (1997) reported that Azolla tolerates different concentration of copper.

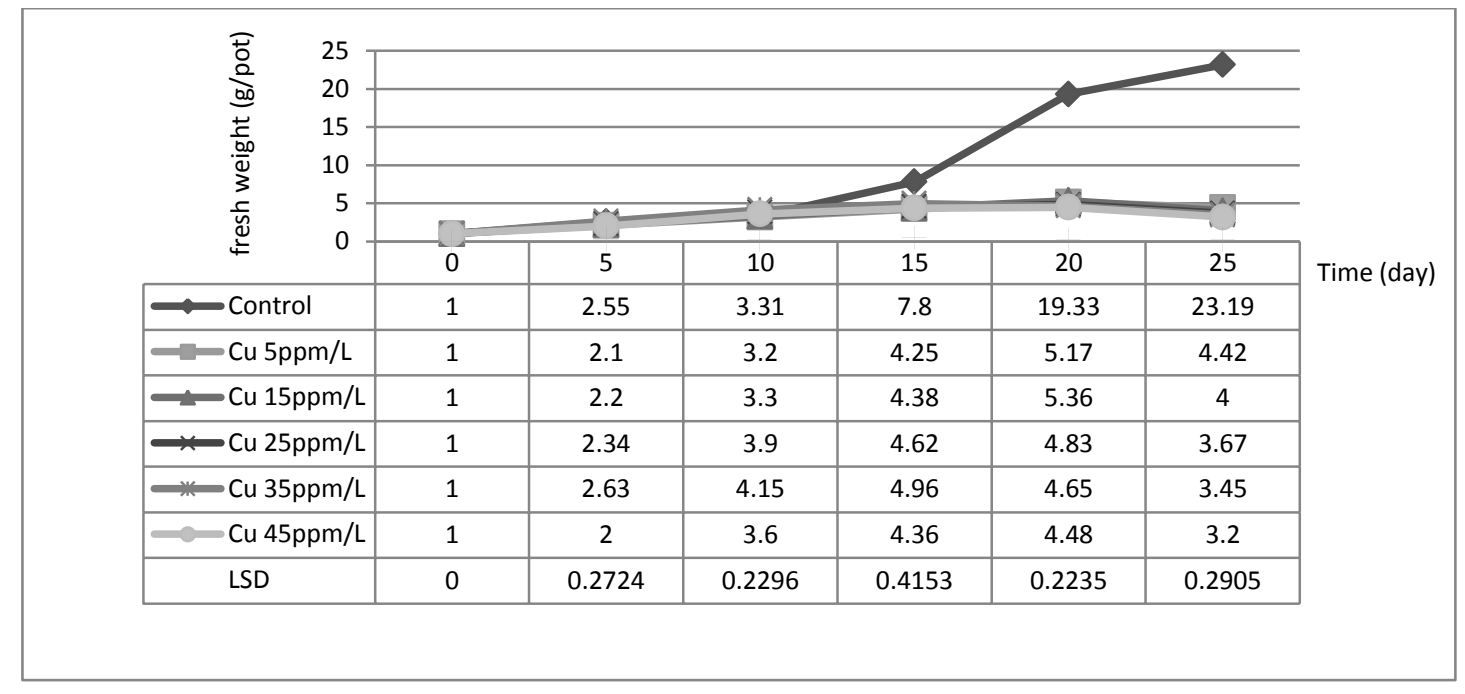

Fig. 14. Effect of different concentrations of $\mathrm{Cu}^{+2}$ on fresh weight (g/pot)of Azolla pinnata grown on Yoshida medium 


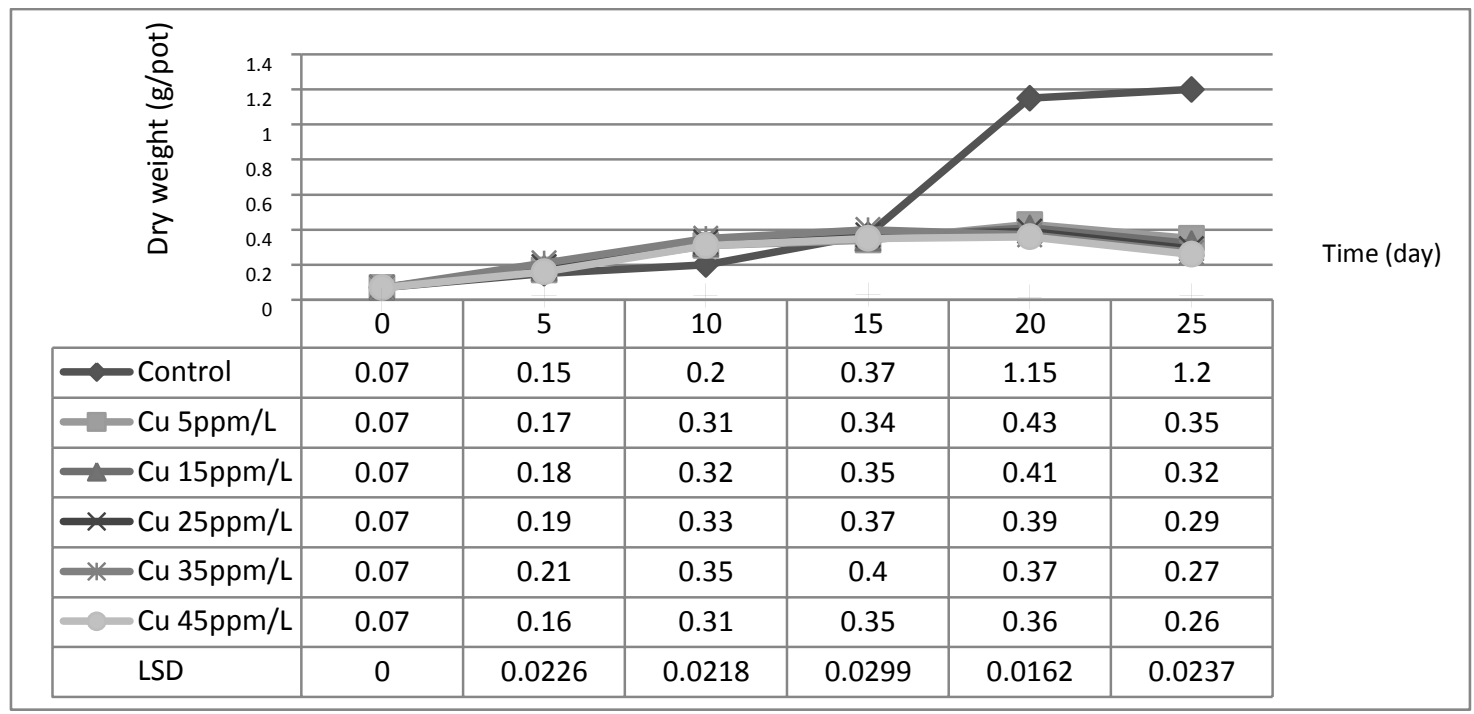

Fig. 15. Effect of different concentrations of $\mathrm{Cu}^{+2}$ on dry weight (g/pot) of Azolla pinnata grown on Yoshida medium

\begin{tabular}{|c|c|c|c|c|c|c|}
\hline \multirow{2}{*}{$\frac{\substack{n \\
\frac{\pi}{0}}}{\stackrel{0}{0}}$} & \multicolumn{6}{|c|}{$+2+2$} \\
\hline & $\begin{array}{l}\text { zero } \\
\text { time }\end{array}$ & 5 & 10 & 15 & 20 & 25 \\
\hline control & 0 & 3.7 & 5.81 & 5.06 & 4.68 & 5.51 \\
\hline$-\mathrm{Cu} 5 \mathrm{ppm} / \mathrm{L}$ & 0 & 4.67 & 5.55 & 7.21 & 8.26 & 11.68 \\
\hline$\longrightarrow \mathrm{Cu} 15 \mathrm{ppm} / \mathrm{L}$ & 0 & 4.42 & 5.31 & 7.04 & 8.43 & 12.5 \\
\hline$\because \mathrm{Cu} 25 \mathrm{ppm} / \mathrm{L}$ & 0 & 4.09 & 5.1 & 7.2 & 8.81 & 13.36 \\
\hline$\because \mathrm{Cu} 35 \mathrm{ppm} / \mathrm{L}$ & 0 & 3.59 & 4.87 & 6.49 & 9.04 & 14.04 \\
\hline$-\mathrm{Cu} 45 \mathrm{ppm} / \mathrm{L}$ & 0 & 5 & 5.43 & 7.07 & 9.25 & 14.97 \\
\hline LSD & 0 & 7.6591 & 5.9838 & 4.2479 & 2.3578 & 9.1801 \\
\hline
\end{tabular}

Time (day)

Fig. 16. Effect of different concentrations of $\mathrm{Cu}^{+2}$ on doubling time (days) of Azolla pinnata grown on Yoshida medium

\section{References}

Abd El-Aal Ana, A.M. 2013. Influence of algal growth on physical and chemical characters of soil. Ph.D. Thesis, Fac. Sci., El-Zagazig Univ., Cairo, Egypt.

Akpor, O.B. and Muchie, M. 2010. Remediation of heavy metals in drinking water and wastewater treatment system: Processes and applications. International Journal of the Physical Sciences, 5(12), 1807-1817.
Alam, M.G.M., Snow, E.T. and Tanaka, A. 2003. Arsenic and heavy metal contamination of vegetables grown in Samta village, Bangladesh. Science of the Total Environment, 308, 8396.

Andrade, L.R., Farina, M. and Amado, G.M. 2004. Effects of copper on Enteromorpha flexuosa (Chlorophyta) in vitro. Ecotoxicol. Environ. Safe., 58, 117-125. 
Arora, A., Saxena, S. and Sharma, D.K. 2006. Tolerance and phytoremediation of chromium by three Azolla species. World Journal of Microbiology \& Biotechnology. 22, 97-100.

Ashton, P.J. and Walmsley, R.D. 1976. The aquatic fern Azolla and its Anabaena symbiont. Endeavour, 35, 39-43.

Aziz, T. and watanabe, I. 1983. Influence of nutrients on the growth and mineral composition of Azolla pinnata. Bangladesh J. Bo., 12(2), 166170.

Black, C.A. (ed.), 1965. Methods of soil analysis, Part2, chemical and microbiological properties, American society of Agronomy, Inc. publisher, Midson, Wisconsin, USA.

Bennicelli, R., Stepniewska, Z., Banach, A., Szajnocha, K. and Ostrowski, J. 2004. The ability of Azolla caroliniana to remove heavy metals $(\mathrm{Hg}(\mathrm{II}), \mathrm{Cr}(\mathrm{III}), \mathrm{Cr}(\mathrm{VI})$ from municipal wastewater. Chemosph., 55, 141-146.

Brown, J.D. and Lilliland, O. 1946. Rapid determination of potassium and sodium in plant material and soil extracts by flame photometry. Proc. Amer. Soc. Hort. Sci., 48, 341-346.

Celebi, S. and Kindir, S. 2002. Toxicity assessment of dye industry treatment sludge. Waste Manage. Res., 20, 541-545.

Cseh, E. 2002. Metal permeability, transport and efflux in plants. In Prasad, M.N.V., Strzakka, K. (Ed.). physiology and Biochemistry of metal Toxicity and Tolerance in Plants. Kluwer Academic Publisher, Dordrecht. pp. 1-36.

El-Araby, Magda, M., El-Shahat, R.M. and ElBerashi, N.Y. 1999. Comparison between Azolla pinnata and Azolla filiculoides application as green manure. In: Development of the desert Environment in Egypt. $\mathrm{VI}^{\text {th }}$ National Conference on Environmental studies and research II. Institute of Environmental Studies and Research. Ain Shams Univ., Cairo, Egypt, pp, 445-460.

El-Berashi Nadia, M.Y. 2008. Impact of Azolla in increasing rice production and reducing environmental pollution In Ph.D. Ain Shams University. pp,110-157.

El-Shahat, R.M. 1988. Prospects of Azolla as biofertilizer in Egyptian conditions. MSc. Thesis, Faculty of Agric., Ain Shams University, Cairo, Egypt, pp. 53-72.

El-Shahat, R.M. 1997. Prospects of Azolla as biofertilizer in Egypt. Ph.D., Thesis In Agricultural Microbiology, Department of Agric. Botany, Faculty of Agriculture, Ain Shams University, Cairo, Egypt. pp. 77-83.
El-Shaymaa, S. Mussa 2005. Role of Azolla in different ecosystem M.Sc. Thesis, Botany Dept. Fac. Sci., (Girls Branch), Al-Azhar, University, Cairo, Egypt. pp. 35-37.

Erakhrumen, A. A. 2007. Phytoremediation: an environmentally sound technology for pollution prevention, control and remediation in developing countries: Educational Research and Review, 2(7), 151-156.

Ferentinos, L., Smith, J. and Valenzuela, H. 2002. Azolla. Sustainable Agriculture Green Manure Crops Aug., SAGM-2.

Fodor, F. 2002. Physiological responses of vascular plants to heavy metals. In: Prasad, M. N. V. Strzatka, K. (Eds.), Physiological and Biochemistry of Metal Toxicity and Tolerance in Plants. Kluwer Academic Publisher, Netherlands. pp.149-177.

Gardea, T.J.L. 2003. Phytoremediation: Where does it stand and where will it go? Environ. Progress, 22(1), A2-A3.

Hardy, R.W.F., Burns, R.C. and Holsten, R.D. 1973. Application of acetylene-ethylene assay for measurement of nitrogen fixation, Soil. Biol. Biochem. 5, 47-81.

Hazrat, A., Ezzat, K. and Muhammad, A.S. 2013. Phytoremediation of heavy metals-Concepts and applications. Chemosphere, 91, 869-881.

Ho, K.C., Chow, Y.L. and Yau, J.T.S. 2003. Chemical and microbiological qualities of The East River (Dongjiang) water with particular reference to drinking water supply in Hong Kong. Chemosphere, 52, 1441-1450.

IFAS 2001. Center of aquatic and invasive plant. University of Florida (IFAS). 59, 26-11-2011.

Ma, M., Zhu, W., Wang, Z. and Witkamp, G.J. 2003. Accumulation, assimilation and growth inhibition of copper in fresh water algae (Scenedesmus subspicatus $86.81 \mathrm{SAG}$ ) in the presence of EDTA and fulvic acid. Aquat. Toxicol., 63, 221-228.

Mashkani, S.G. and Ghazvini, P.T.M. 2009. Biotechnological potential of Azolla filiculoides for biosorption of $\mathrm{Cs}$ and Sr: application of microPIXE for measurement of Biosorption. Bioresouce Technology, 100, 1915-1921.

Migocka, M. and Klobus, G. 2007. The properties of the $\mathrm{Mn}, \mathrm{Ni}$ and $\mathrm{Pb}$ transport operating at plasma membranes of cucumber roots. Physiologia. Plantarum., 129, 578-587.

Miller, J.R., Hudson, E.K.A., Lechler, P.J., Preston, D. and Macklin, M.G. 2004. Heavy metal contamination of water, soil and produce within riverine communities of the Rio Pilcomayo ba- 

Heavy metals

sin, Bolivia. Sci. total Environment, 320, 189209.

Monica, M., Chinmay, P. and Kunja, B.S. 2014. Decontamination of Lead from aquatic environment by exploitation of floating macrophyte $A z$ olla microphylla Kauf., 8(12),17-23.

Moore, A.W. 1969. Azolla: Biology and agronomic significance. Botanical Review, 35, 17-34.

Nour El-Din, E.M. 1997. Use of Azolla as biofertilizer to reduce the dependence on the chemical fertilizer. M.Sc. Thesis, Institute of environmental studies and research, Ain Shams University. pp. 137-142.

Nuzhat Shafi, Ashok K. Pandit, Azra N. Kamili, Basharat Mushtaq. 2015. Heavy Metal Accumulation by Azolla pinnata of Dal Lake Ecosystem, India, J. of Environment Protection and Sustainable Development ,1(1), 8-12..

Olsen, S.R. and Sommers, L.E. 1982. Phosphorus. In page $\mathrm{Al}$, et al (eds.), Methods of soil analysis, part2, $2^{\text {nd }}$ ed, Agron. Monogr. 9 ASA and ASSA, Madison WI, pp. 403-430.

Orcutt, D.M. and Nilsen, E.T. 2000. Physiology of Plants under Stress: Soil and Biotic Factors. John Wiley \& Sons, Inc. New York. 26, 27-40.

Pabby, A., Prasanna, R. and Singh, P.K. 2004. Biological significance of Azolla and its utilization in agriculture. Pro. Indian Natl. Sci. Acad. BTO., 70, 301-335.

Page, A.L., Miller, R.H. and Keeney, D.R. (eds.) 1982. Methods of soil analysis: part2, chemical and microbiological properties Agronomy, series No 9, American society of Agronomy, Madison, WI.

Peters, G.A. and Mayne, B.C. 1974. The AzollaAnabaenaazollae relationship. Initial characterization of the association. Plant Physiol., 53, 813-819.

Pilon, S.E. 2005. Ground Water Issue: Phytoremediation of contaminated soil and ground water at hazardous waste sites, pp. 1-36.

Punita, S.P. and Soma, K.M. 2015. Capacity of Azolla pinnata var. imbricata to absorb heavy metals and fluorides from the wastewater of oil and petroleum refining industry at Vadodara. International Peer Reviewed Referred J., II (I), 37-43.
Rai, P. 2011. An eco-sustainable green approach for heavy metals management: two case studies of developing industrial region, environmental Monitoring and Assessment, pp. 1-28.

Rai, P.K. 2007. wastewater management through biomass of Azolla pinnata: An ecosustainable approach. Ambio., 36(5), 426-428.

Rai, P.K. 2008a. Heavy-metal pollution in aquatic ecosystems and its phytoremediation using wetland plant: An eco-sustainable approach. Int. J. Phytoremediation, 10(2), 133-160.

Rai, P.K. 2008b. Phytoremediation of $\mathrm{Hg}$ and $\mathrm{Cd}$ from industrial effluents using an aquatic free floating macrophyte Azolla pinnata Int. J. Phytorem., 10, 430-439.

Rai, P.K. 2009. Heavy metal phytoremediation from aquatic ecosystems with special reference to macrophytes. Critical Reviews in Environmental Science and Technology, 39(9),697753.

Sheo, M.P. and Anita, S. 2011. Metabolic responses of Azolla pinnata to cadmium stress: photosynthesis, antioxidative system and phytoremediation. Chemistry and Ecology, 27(6), 543-555.

Sood, A., Perm, L., Prasanna, U.R. and Ahluwalia, A. S. 2012. Phytoremediation potential of aquatic macrophyte, Azolla. A Journal of the Human Environment, 41, 122-137.

Thayaparan, M., Iqbal, S.S., Chathurannga, P.K.D. and lqbal, M.C.M. 2013. Rhizofiltration of $\mathrm{Pb}$ by Azolla pinnata. International Journal of Environmental Sciences, 3(6), 1811-1821.

Upadhyay, A.R., Mishra, V.K., Pandey, S.K. and Tripathi, B.D. 2007. Biofiltration of secondary treated municipal wastewater in a tropical city. Ecological Engineering, 30(1), 9-15.

Wagner G.M. 1997. Azolla: a review of its biology and utilization Bot. Rev., 63- 1997, pp.1-26.

Yoshida, S., Forno, D.A., Cock, J.H. and Gomez, K.A. 1976. Laboratory Manual for Physiological Studies of Rice. The International Rice Research Institute(IRRI), Los Baños, Philippines. $83 \mathrm{p}$.

Zimmels, Y., Kirzhner, F. and Roitman, S. 2004. Use of naturally growing aquatic plants for wastewater purification. Water Environ. Res., 76(3), 220-230. 